\author{
辻 明宏* 張 朔源** 橋本 匡史*** \\ 岡野 成威 $* * * *$ 菖蒲 敬久 $* * * * *$ 望月 正人****
}

\title{
In-Situ Measurement of Transitional Stress in Welds Metal of Steel Using Synchrotron Radiation
}

by

\author{
Akihiro TSUJI ${ }^{*}$, Shuoyuan ZHANG $^{* *}$, Tadafumi HASHIMOTO ${ }^{* * *}$, \\ Shigetaka OKANO ${ }^{* * * *}$, Takahisa SHOBU ${ }^{* * * * *}$ and Masahito MOCHIZUKI ${ }^{* * * *}$
}

\begin{abstract}
It is necessary to control weld residual stress which has negative influence on fracture strengths. In structural steel welds, complex residual stress fields are formed due to phase transformation that occur according to the thermal cycles. Therefore, it is important to evaluate the stress generating process during phase transformation in welding. In this study, in-situ evaluation of phase transformation and transitional stress simultaneously during welding is discussed.

In the test using SM490A, after cooling process, stress evaluated by this system showed good agreement with that evaluated by lab X-ray. During austenite to ferrite transformation in weld metal, tensile stress occurred in austenite and compressive stress occurred in ferrite. These behavior are agree with internal stresses behavior depend on phase transformation strain and the difference of thermal expansion rate between ferrite and austenite. Moreover, stress concentration was occurred in ferrite phase immediately after the start of phase transformation. Also, stress concentration was occurred in austenite phase just before the end of phase transformation. Thus in-situ observation phase transformation and stress simultaneously during welding and phase transformation process can be done in weld metal.
\end{abstract}

\section{Key words:}

Welding, SM490A, Residual stress, In-situ stress measuring, Synchrotron radiation

\section{1 緒言}

化学プラント, 自動車, 船舶, 各種産業機械, 社会基盤 構造物など, 我が国の基幹産業を支えるものは溶接構造 物である場合がほとんどである。しかし，今日これらの構 造物において疲労や応力腐食割れなどによる問題が顕在 化しており，損傷の発生原因の 1 つとして溶接部の残留 忘力が重要視されている ${ }^{1)-4)}$. そのため, 溶接構造物の構 造安全性向上のための取り組みにおいて, 溶接部に生じ ている応力を正確に評価し, 適切に対処することが求め られている.ここで, 構造用材料の多くでは, 熱サイクル に応じて生じる相変態によって溶接部に複雑な残留応力 場が形成される. 特に, 冷却過程の相変態による膨張, 収 縮は溶接後の残留応力に大きく影響を及ぼす. 溶接残留 忘力評価に積極的に取り入れられている数值解析におい ては, 相変態に伴う応力変化挙動を溶接部の冷却速度と 関連付けてモデル化 5 (6)寸るなどして計算が行われており,
高精度な計算手法が確立されつつある. しかし, 相変態中 の応力挙動は相変態による膨張, 収縮だけでなく, 各相の 機械的特性や熱膨張係数の差に起因した内部応力などに よっても左右され, それらの挙動は相の体積比の変化と 共に逐次変化する. これらの挙動を現状の数值解析手法 にフィットするようなモデルで表すことは極めて困難で あり，数值解析によるアプローチのみで正確な残留応力 評価を行うことは必ずしも現実的ではない. さらに, 現実 を忠実に模擬した詳細な解析モデルを作成できたとして も, 解析モデルを検証するための何らかの実測值が必要 である. そのため, 構造用材料の溶接残留応力をより正確 に評価するためには, 溶接中の過渡的な応力挙動や冷却 時の相変態に起因した応力変化を実験的に評価すること が望まれる。

放射光は高輝度・高強度・高指向性な X 線が利用でき ることから時分割で様々な現象を非破壊的に計測するこ

$\dagger$ 原稿受理 平成27年12月20日 Received Dec. 20, 2015 @2016 The Society of Materials Science, Japan

* 学 生 会 員 大阪大学 大学院 工学研究科 マテリアル生産科学専攻 テ565-0871 吹田市山田丘 Graduate School of Engineering, Osaka University, Yamadaoka, Suita, 565-0871.

** 非 会 員 (財)総合科学研究機構 ₹319-1106 茨城県那珂郡東海村白方

Comprehensive Research Organization for Science and Society, Naka-gun, Ibaraki, 319-1106.

*** 正 会 員 橋本鉄工株式会社 干509-0982 堺市堺区海山町

Hashimoto Iron Works Co., Ltd., Sakai-ku, Sakai, 509-0982.

**** 正 会 員 大阪大学 大学院 工学研究科 マテリアル生産科学専攻 †565-0871 吹田市山田丘 Graduate School of Engineering, Osaka University, Yamadaoka, Suita, 565-0871.

***** 正 会 員 (国研) 日本原子力研究開発機構 原子力科学研究部門 量子ビーム応用研究センター 放射光量子物性研究ディビジョン 高圧・応力科学研 究グループ $\bar{\top} 679-5148$ 兵庫県佐用郡佐用町

Japan Atomic Energy Agency, Sector of Nuclear Science Research Quantum Beam Sci. Directorate High Pressure Science and Stress Research Group, Sayou-gun, Hyogo, 679-5148. 
とが可能であり, 近年, 放射光を用いて溶接中に生じる現 象を実験的に明らかにしようとする試みが積極的に行わ れている. Eimaer $ら^{7) や K o m i z o ~} ら^{8)}$ は凝固現象や相変態 挙動の in-situ 観察を実施し，それらの成果が詳細に報告 されている.本研究では, 著者らのグループが開発した insitu 計測システム 9)を活用し, 溶接中の過渡的な応力変化 を相変化を含めて同時に計測することで，溶接熱サイク ルに伴う相変態に起因した過渡的な応力発生挙動につい て詳細に考察した。

\section{2 試験要項}

\section{$2 \cdot 1$ システムの概要}

本研究で構築した溶接過渡応力の in-situ 計測システム の外観と模式図を Fig. 1 に示す。本システムは複数台の 2 次元検出器とガスタングステンアーク溶接(Gas Tungsten Arc 溶接：GTA 溶接)システムから構成されている。測定 は反射法で行われ，放射光ビーム焦点に溶接システムを 設置することで，溶接中の回折リングを評価することが 可能である．また，Fig. 2 に示すように，溶接システムの 位置に高温引張試験機を設置し，透過法を用いることで， 光学系を大きく変化することなく高温引張試験中の忘力 計測を行うこともできる．本システムは大型放射光施設 (SPring-8)にある国立研究開発法人日本原子力研究開発機 構(JAEA)のアンジュレータビームライン BL22XU に構築 された.アンジュレータ光源から得られる準白色 $\mathrm{X}$ 線は $\mathrm{Si}$ 単結晶の $\{111\}$ 回折を利用し， $30 \mathrm{keV}$ のエネルギーに単 色化した. なお, 本研究では鉄系材料を対象としており, フェライト相 $(\alpha$ 相)とオーステナイト相 $(\gamma$ 相 $)$ の相変態に 起因した応力生成過程の in-situ 計測を目的の 1 つとして いる．エネルギーを $30 \mathrm{keV}$ とすることで，弾性定数の回 折面依存性が小さいとされる $\alpha\{211\}$ ならびに $\gamma\{311\}^{10), 11)}$ を同一検出器内で同時に検出できる.また, 溶接時には応 力以外にも熱膨張により格子面間隔が変化するため, 正 確な無ひずみの格子面間隔(回折角)を必要とせず, 熱膨張 による格子定数の変化の影響が小さい $2 \theta-\sin ^{2} \psi$ 法 ${ }^{12)}$ によ る応力算出が望ましいが, $2 \theta$ - $\sin ^{2} \psi$ 法は複数回の計測を必 要とする.しかし，本システムでは Fig. 1 (b)，Fig. 2(b)に 示すように, 複数の 2 次元検出器を用いて $2 \theta$ と $\sin ^{2} \psi$ の 関係を複数同時評価することで 1 回の計測から $2 \theta-\sin ^{2} \psi$ 法による応力算出が可能である.さらに, 検出器に時間分 解能に優れる PILATUS を用いることで，放射光を照射し 続ける中でリアルタイムに応力変化を追従できる．本シ ステムで用いる検出器は 2 台の PILATUS-100K(検出面積: $83.8 \times 33.5 \mathrm{~mm}$ ) と 1 台の PILATUS-300K(検出面積 : $83.8 \times$ $106.5 \mathrm{~mm}$ )である. PILATUS-100K は試験体から $1000 \mathrm{~mm}$ の位置に, PILATUS-300K は $230 \mathrm{~mm}$ の位置にそれぞれ設 置され，それぞれの検出器は自動ステージにより自由に 移動でき, 必要とする回折リングを検出できる. 試験体近 くに設置された PILATUS-300K では多数の回折リングを 検出でき, 試験中の相変態挙動を観察できる. 角度分解能 を向上させるため離れて設置された PILATUS-100K では 回折リングの一部を検出でき, 応力, 温度の変化に伴う回

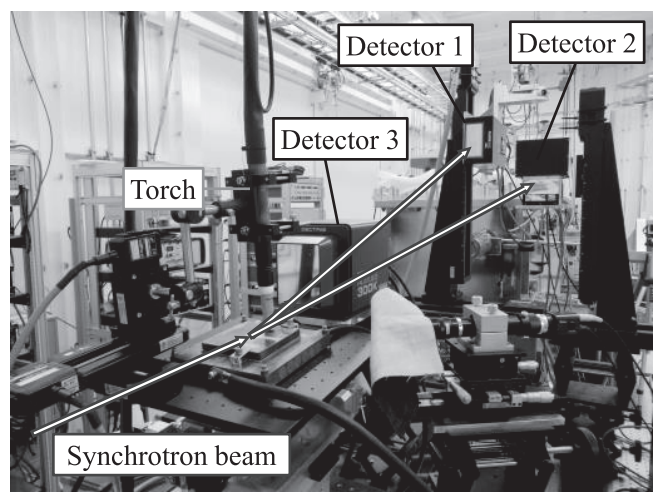

(a) Photograph

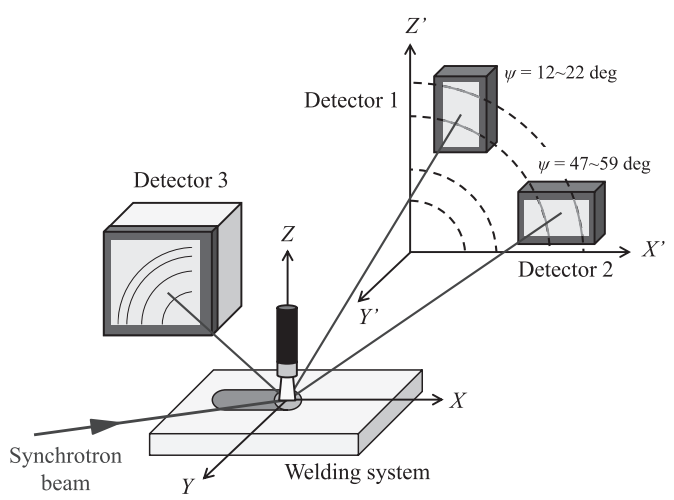

(b) Schematic image

Fig. 1 Appearance of in-situ stress measuring system during welding.

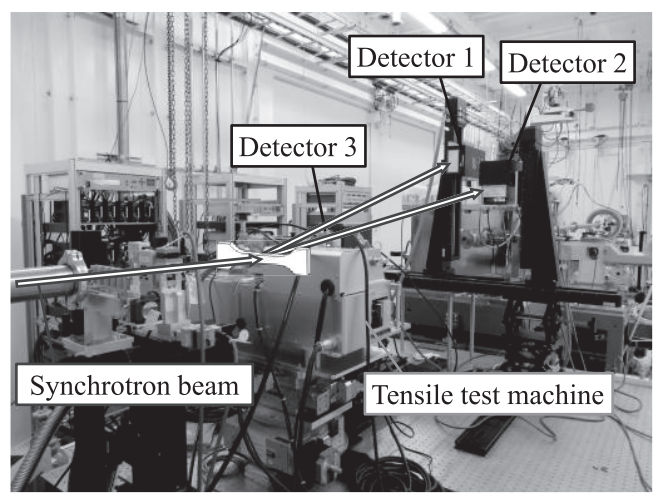

(a) Photograph

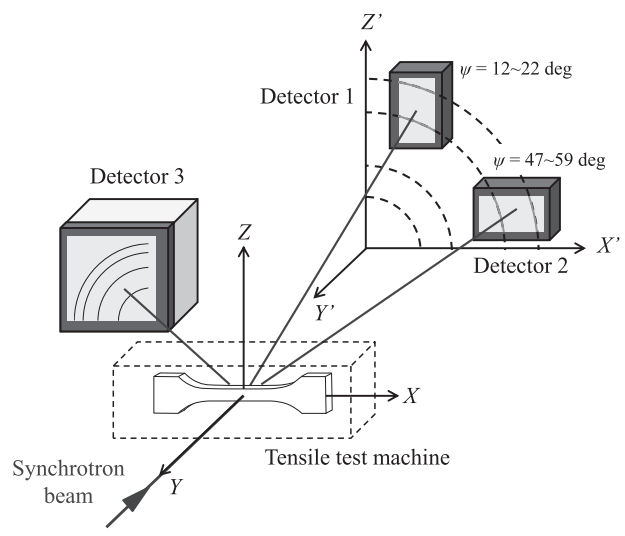

(b) Schematic image

Fig. 2 Appearance of in-situ stress measuring system during tensile test. 
折角の変化を観察できる. なお, $2 \theta-\sin ^{2} \psi$ 法による応力解 析に必要な散乱ベクトル分布(Fig. 1, Fig. 2 中の $X-Y-Z$ 座 標系)と, 2 次元検出器に記録された回折データの散乱べ クトル分布（Fig. 1, Fig. 2 中の $X^{\prime}-Y^{\prime}-Z^{\prime}$ 座標系）のズレは 座標変換により修正し，本研究では $\psi=12 \sim 22 \mathrm{deg}$ ならび に $\psi=47 \sim 59 \mathrm{deg}$ の範囲の回折から応力を算出した。溶接 システムは溶接トーチと試験体を同一ステージに固定す る方法を選択した。 これにより, 溶接ステージを回転させ ることで, 任意の方向の応力評価が可能となった. 計測時 には放射光の照射位置は 1 点に固定され，溶接トーチが 試験体上を横断する．機器の設置角度などに起因した誤 差は，事前に無ひずみサンプル $\mathrm{CeO}_{2}$ の回折を取得し，対 象とする回折付近が無応力となる補正係数を決定し補正 した. $\alpha\{211\}$ に対しては $\mathrm{CeO}_{2}\{420\},\{422\}$ から， $\gamma\{311\} に$ 対しては $\mathrm{CeO}_{2}\{422\},\{511\}$ から補正係数を算出した.

\section{$2 \cdot 2$ 供試材料}

供試材料として溶接構造用圧延鋼材 SM490Aを用いた. 供試材料の化学組成と機械的特性を Table 1, Table 2 に示 す. X 線的弾性定数評価のための高温引張試験片の寸法 は，標点間距離 $20 \mathrm{~mm}$ ，板幅 $4 \mathrm{~mm}$ ，板厚 $0.3 \mathrm{~mm}$ であり， 溶接試験体と同じロットから放電加工により作成した. 溶接試験体の寸法は，板長 $100 \mathrm{~mm}$, 板幅 $100 \mathrm{~mm}$, 板厚 $10 \mathrm{~mm}$ であり, 温度 $600^{\circ} \mathrm{C}$, 保持時間 $6 \mathrm{~h}$ の条件で熱処理 を行った．熱処理時に生じた表面酸化膜は研磨紙で削り 落とし, 応力計測を行う試験体中央部に電解研磨を施し 表面の研磨層を除去した。

Table 1 Chemical composition of SM490A (mass \%).

\begin{tabular}{|cccccccc|}
\hline $\mathrm{C}$ & $\mathrm{Si}$ & $\mathrm{Mn}$ & $\mathrm{P}$ & $\mathrm{S}$ & $\mathrm{Ni}$ & $\mathrm{Cr}$ & $\mathrm{V}$ \\
\hline 0.16 & 0.39 & 1.38 & 0.016 & 0.004 & 0.01 & 0.02 & 0.002 \\
\hline
\end{tabular}

Table 2 Mechanical properties of SM490A. \begin{tabular}{|lll|}
\hline Yield stress $(\mathrm{MPa})$ & Tensil strength $(\mathrm{MPa})$ & Elongation $(\%)$ \\
\hline
\end{tabular} 381 25

\section{$2 \cdot 3$ 高温引張試験条件}

供試材料の $\mathrm{X}$ 線的弾性定数の温度依存性評価のため, 高温引張試験を行った。試験の際にはアルゴンガスによ るガス置換を行い, その後, 炉内を真空状態(約-50 kPa)に した。高温引張試験は室温から $700^{\circ} \mathrm{C}$ までを約 $100^{\circ} \mathrm{C}$ 間 隔で行った。昇温は加熱速度 $10^{\circ} \mathrm{C} / \mathrm{s}$ で行い, 試験温度に 達してから $60 \mathrm{~s}$ 保持した後, 引張試験を開始した。 引張 試験は荷重制御で行い, 荷重速度は $1 \mathrm{~N} / \mathrm{s}$ である。 また, 引張試験開始前は熱膨張によって生じる試験片と治具と の間の遊びをなくす目的で $1 \sim 2 \mathrm{~N}$ の荷重を負荷し続けた 回折の計測は昇温開始から引張終了まで $0.5 \mathrm{~s}$ 間隔で行っ た. X 線的弾性定数は, 負荷応力と $2 \theta-\sin ^{2} \psi$ 線図の関係式 (1), (2)から求めた ${ }^{13)}$.

$$
\begin{aligned}
& \frac{2\left(1+v_{h k l}\right)}{E_{h k l}}=-\cot \theta_{0} \cdot \frac{\partial M}{\partial \sigma_{A}} \cdot \frac{\pi}{180} \\
& \frac{v_{h k l}}{E_{h k l}}=\frac{\cot \theta_{0}}{2} \cdot \frac{\partial 2 \theta_{\psi=0}}{\partial \sigma_{A}} \cdot \frac{\pi}{180} \\
& E_{h k l}: \mathrm{X} \text { 線的ヤング率 } \\
& v_{h k l}: \mathrm{X} \text { 線的ポアソン比 } \\
& 2 \theta_{\psi=0}: 2 \theta-\sin ^{2} \psi \text { 線図の切片 }
\end{aligned}
$$

\section{$2 \cdot 4$ 溶接条件}

溶接法は GTA 溶接によるビードオンプレートとし, 溶 接電流 $150 \mathrm{~A}$, 溶接速度 $1 \mathrm{~mm} / \mathrm{s}$, アーク長 $3 \mathrm{~mm}$, シール ドガス $100 \% \mathrm{Ar}$ ，シールドガス流量 10 l/min とした。電 極は直径 $3.2 \mathrm{~mm}$ の $2 \%$ 酸化セリウム入りタングステン電 極を使用し, 突き出し長さは $5 \mathrm{~mm}$ とした。 また, 溶接熱 のゴニオメータへの影響を排除するための水冷胴板を試 験体とゴニオメータとの間に設けているが，これにより 冷却速度が大きくなることが懸念された. そこで, 試験体 と水冷胴板との間に熱伝導率の小さいステンレス板 (SUS316L, 板厚 $3 \mathrm{~mm})$ を 1 枚挟んだ.

\section{$2 \cdot 5$ 応力計測条件}

応力計測は，溶接金属部(溶接線中央)で行い, アークの 点弧と同時に開始し, $0.1 \mathrm{~s}$ 間隔で $300 \mathrm{~s}$ 行った. 計測の際, 試験体を入射ビームに対し $5 \mathrm{deg}$ 傾けたが, 照射領域は溶 接線方向に $1 \mathrm{~mm}$, 溶接線直交方向に $0.5 \mathrm{~mm}$ になるよう スリットで制御した。

\section{$2 \cdot 6$ 相変態挙動の評価方法}

本研究では混合組織中のある相の回折強度がその体積 比に比例することを利用し ${ }^{15)}$ ，フェライト相とオーステ ナイト相の体積比を求めた. 2 相からなる混合組織の場合, 体積比は式(3)から求めることができる.

$$
\begin{aligned}
& \frac{1}{V_{\gamma}}=1+\frac{R_{\gamma}}{R_{\alpha}} \cdot \frac{I_{\alpha}}{I_{\gamma}} \\
& R=\frac{1}{v^{2}}|F|^{2} p L P \exp (-2 M) \\
& V_{\alpha, \gamma} \text { : 各相の体積比 } \\
& F: \text { 構造因子 } \\
& L P \text { : ローレンツ偏り因子 } \\
& v \text { : 単位格子の体積 } \\
& p: \text { 多重度因子 } \\
& e^{(-2 M)}: \text { 温度因子 }
\end{aligned}
$$

また, 回折強度の変化は PILATUS-300K から得られる画 像を用いて評価した。 得られた 2 次元データを European Synchrotron Radiation Facility(ESRF)で開発されたデータ解 析用プログラム Fit2d を用いて 1 次元化し, 回折強度の時 間変化から体積比の時間変化を評価した. なお, 配向, 粗 大粒の影響を軽減するため, 複数の回折の組み合わせか ら体積比を評価し, その平均值を用いた. 用いた回折面は $\alpha\{200\},\{211\},\{220\}$, および $\gamma\{220\},\{311\},\{222\}$ であ る.

\section{$2 \cdot 7$ ラボ X 線による残留応力計測条件}

溶接後の試験片の残留応力評価にはラボ $\mathrm{X}$ 線である Rigaku 社製の AutoMATE を用いた. Cr-K $\alpha$ 線の $\{211\}$ 回折 面を用い, 照射領域は直径 $1 \mathrm{~mm}$ に制限した。 応力算出に は $2 \theta-\sin ^{2} \psi$ 法を用いた。 


\section{$2 \cdot 8$ 数值解析条件}

溶接金属部の温度履歴は実測が困難であったため，数 值解析により評価した. 数值解析は汎用有限要素法解析 コード ABAQUS ver. 6.13 を用いた有限要素法(FEM)によ って行った．対象は Fig. 3 に示す寸法であり，in-situ 計測 に用いた試験体と同じ寸法である，有限要素モデルは対 称性を考慮し $1 / 2$ モデルとし, 試験体表面および溶接部近 傍では要素分割を細かくしている. 熱源モデルには Okano らが提案した式(6)の熱源モデル 15)を用いた。数值解析で 用いた物性值はFig. 4 の通りであり, 本研究では $q=1234.5$ $\mathrm{J} / \mathrm{s}, \quad r=2.7275 \mathrm{~mm}$ とした。

$$
Q_{(x, y, t)}=\frac{q}{\pi r^{2}} \exp \left\{-\frac{(x-v t)^{2}}{r^{2}}\right\} \exp \left\{-\frac{y^{2}}{r^{2}}\right\}
$$

$$
Q(x, y, t) \text { : 表面熱流束 } \quad v \text { : 溶接速度 } \quad t \text { : 時間 }
$$
$q$ : 単位時間当たりの入熱量 $\quad r$ : 入熱分布の半径

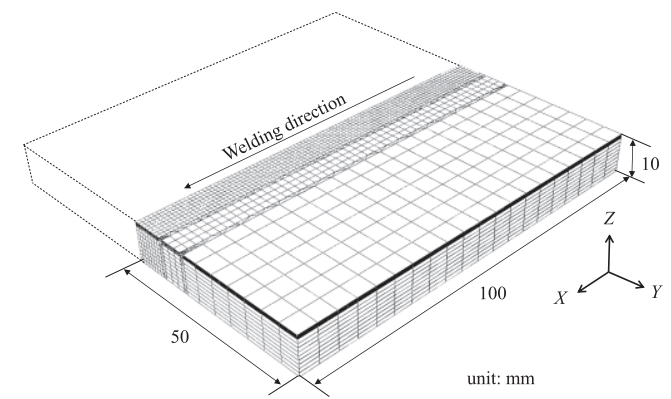

Fig. 3 Finite element model for thermal conductivity analysis.

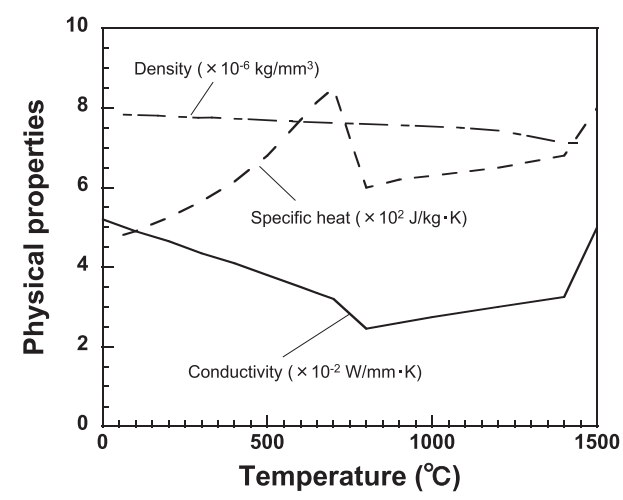

Fig. 4 Material properties used in thermal conduction analysis.

\section{3 実験結果}

\section{$3 \cdot 1 \quad \mathrm{X}$ 線的弾性定数の温度依存性}

Fig. 5 に高温引張試験時の $2 \theta$ - $\sin ^{2} \psi$ 線図を, Fig. 6 に高 温温引張試験から得られた供試材料の $\mathrm{X}$ 線的弾性定数の 温度依存性を示す. Fig. 6 には機械的なヤング率，ポアソ ン比の温度依存性も併せて示す. Fig. 5 (a), (b)に示すよう に, $2 \theta-\sin ^{2} \psi$ 線図の回帰直線は, 温度が変化してもほぼ同 じ 1 点で交わっていることが確認できる. しかし， $700^{\circ} \mathrm{C}$ の試験においては Fig. 5 (c)に示すように, 一方の検出器 (Detector 2)にエラーが生じ, 回折角を得ることができなか った。ここで, 試験温度にかかわらず $2 \theta-\sin ^{2} \psi$ 線図の回帰 直線はほぼ同じ位置で交わり，なおかつ，Fig. 6 (b)より，
供試材料の X 線的ポアソン比の温度依存性は小さいこと が確認できる. そこで本研究では, 式(7)の $2 \theta$ に $2 \theta_{0}$ を代 入した際に得られる式(8)より，回帰直線が交わる位置の $\sin ^{2} \psi$ の值を推測し，その位置に無負荷時の回折角を $2 \theta_{0}$ としてプロットし， $2 \theta-\sin ^{2} \psi$ 線図の傾きと切片を求めた. そのため, Fig. 6 には参考值として $700{ }^{\circ} \mathrm{C}$ の結果を示す.

$$
\begin{gathered}
2 \theta=-\frac{2\left(1+v_{h k l}\right)}{E_{h k l}} \tan \theta_{0} \cdot \sigma_{A} \cdot \sin ^{2} \psi \\
+\frac{v_{h k l}}{E_{h k l}} \tan \theta_{0} \cdot \sigma_{A}+2 \theta_{0} \\
\left.\sin ^{2} \psi\right|_{2 \theta=2 \theta_{0}}=\frac{v}{1+v}
\end{gathered}
$$

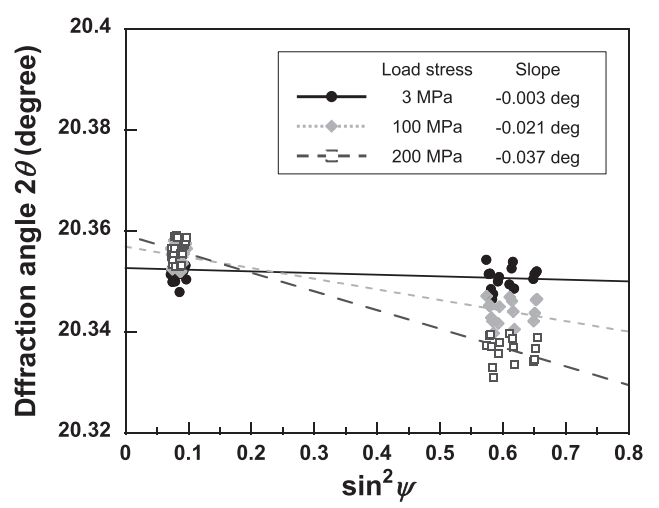

(a) $300{ }^{\circ} \mathrm{C}$

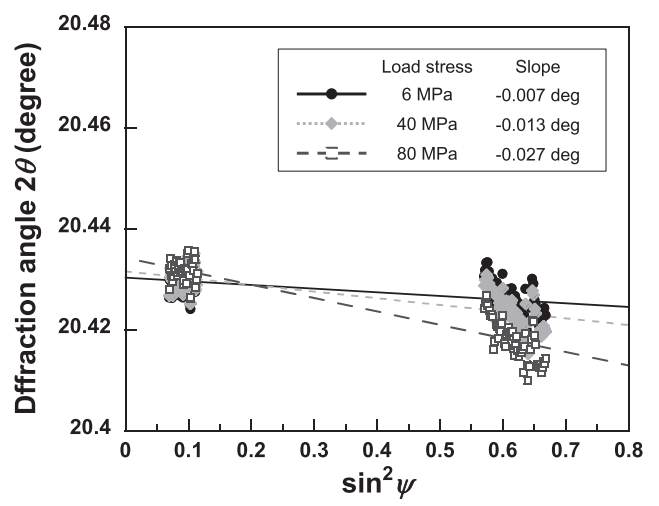

(b) $600^{\circ} \mathrm{C}$

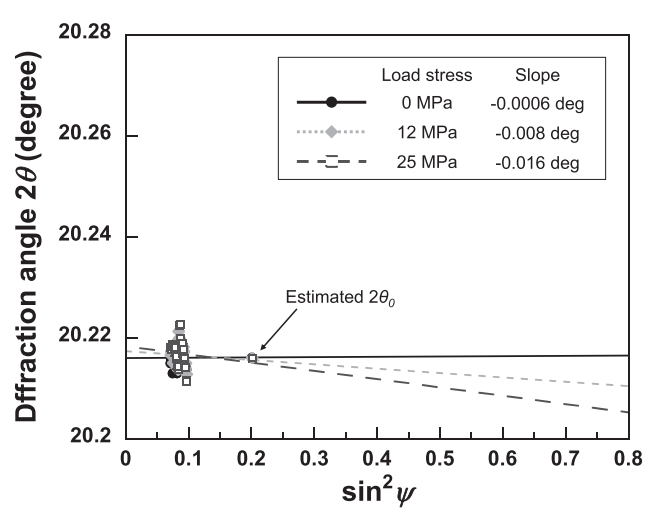

(c) $700{ }^{\circ} \mathrm{C}$

Fig. $52 \theta$ - $\sin ^{2} \psi$ diagram at each temperature. 
Fig. 6 より, SM490A の X 線的ヤング率は温度の上昇と 共に小さくなっており，機械的なヤング率と同じ傾向を 示した。同様に X 線的ポアソン比も機械的なポアソン比 と同じ傾向を示し，温度が上昇してもほぼ一定の值を示 した。なお， $700{ }^{\circ} \mathrm{C}$ 以上の $\mathrm{X}$ 線的弾性定数を評価するこ とが困難であったため，フェライト相に対しては SM490YB の，オーステナイト相に対しては SUS316L の 機械的なヤング率, ポアソン比を用いた。

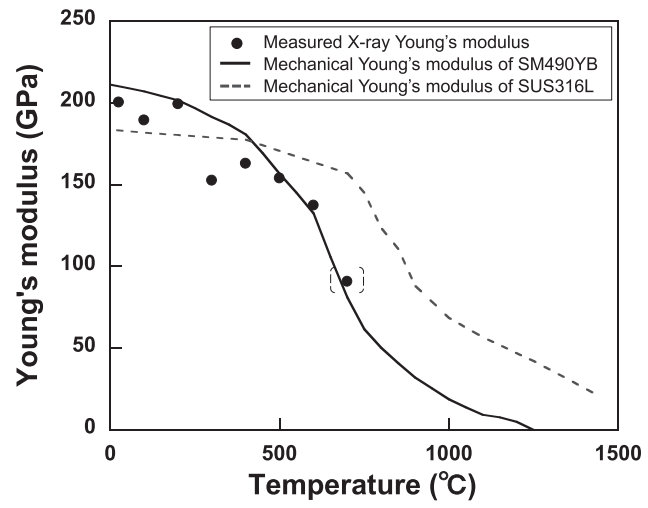

(a) Young's modulus

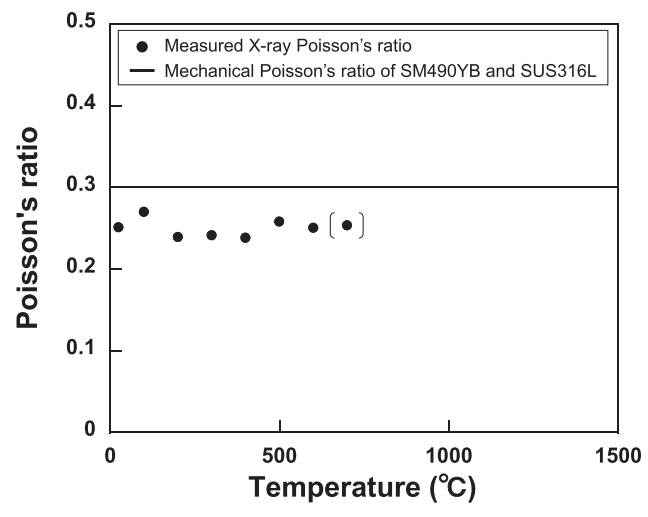

(b) Poisson's ratio

Fig. 6 Temperature dependency of X-ray elastic constant.

\section{$3 \cdot 2$ 温度履歴の解析値と実測值の比較}

数值解析によって溶接時の温度場を正確に模擬できて

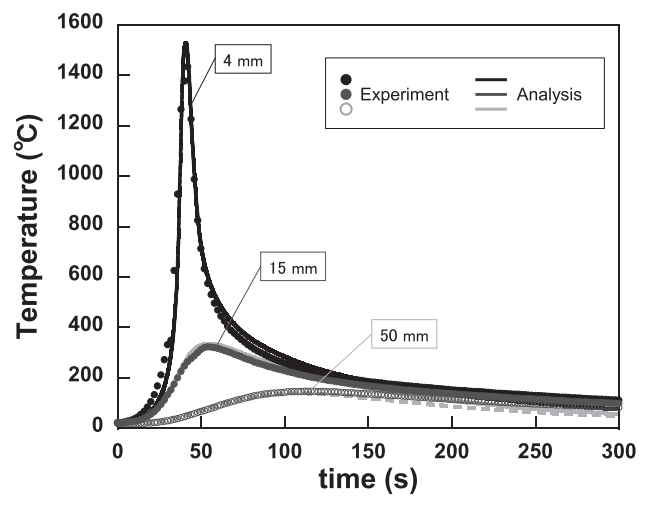

Fig. 7 Comparison of experimental and analytical result of thermal history.
いるか確認するため, 熱電対による実測結果と数值解析 結果を比較した. 熱電対による計測位置は, 溶接中心から $4 \mathrm{~mm}, 15 \mathrm{~mm}, 50 \mathrm{~mm}$ (試験体端部)である. 両者の比較結 果を Fig. 7 に示す。溶接トーチは $0 \mathrm{~s}$ から動き始め, $40 \mathrm{~s}$ で試験体中央に達する. Fig. 7 より数值解析によって得ら れた温度履歴は最高到達温度と最高温度に達する時間, その後の冷却時の挙動において実測值と良好に一致して いることが確認できる. このことから, 本数值解析により 溶接時の温度場を精度よく模擬できていると判断し, 以 降の結果には数值解析で求めた温度履歴を用いた。

\section{$3 \cdot 3$ 溶接過渡応力の in-situ 計測結果}

$3 \cdot 3 \cdot 1$ 冷却中の相変態挙動 PILATUS-300K で得ら れた回折から溶接金属部におけるオーステナイト相の体 積比を算出し, 温度履歴との対応を示したグラフを Fig. 8 に示寸。溶接トーチが計測点直上通を過後 $(40 \mathrm{~s})$, 冷却 されるに伴い約 $620^{\circ} \mathrm{C}(55.8 \mathrm{~s})$ でオーステナイト $\rightarrow$ オ イト変態が始まり, 約 $560^{\circ} \mathrm{C}(58.5 \mathrm{~s})$ まで泠却されるとオ 一ステナイト相の体積比は 0.5 以下になった。 その後, 約 $436{ }^{\circ} \mathrm{C}(68.5 \mathrm{~s})$ まで泠却されると相変態が完了した。な お，本測定では冷却開始直後に現れる $\delta$ フェライト相は 検出することができなかった。

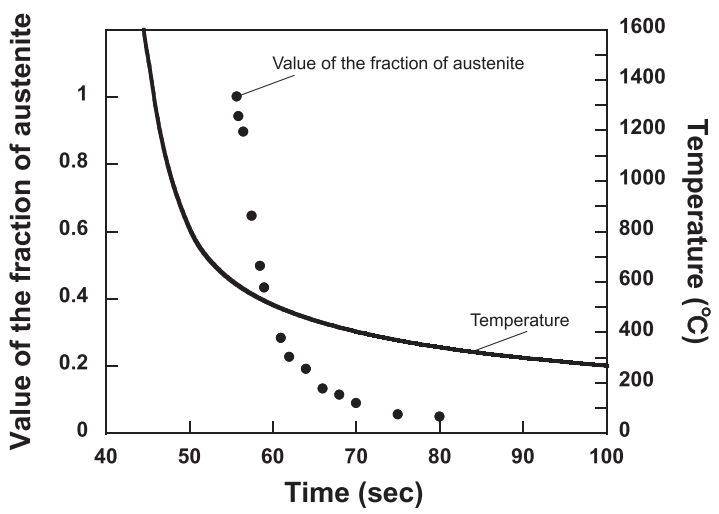

Fig. 8 Phase transformation behavior evaluated by detector 3 at cooling process.

$3 \cdot 3 \cdot 2$ 溶接中の応力変化と相変態との関係 Fig. 9 に溶接線方向の in-situ 計測の結果を示す. Fig. 9 に示す ように，十分冷却された後(300s)の応力值はラボ X 線に よる測定結果に近い值を示した。 さらに，相変態中オー ステナイトーフェライト変態過程におけるオーステナイ ト相とフェライト相の応力をそれぞれ独立して評価でき た。このように，放射光を用いた in-situ 計測技術を用い ることで，溶接金属部における溶接中の相変化と応力変 化を同時に評価することができた．なお，放射光とラボ $\mathrm{X}$ 線による結果に $100 \mathrm{MPa}$ 程度の差があるが，これは溶 接後に生じた粗大粒などの組織変化の影響により $\mathrm{CeO}_{2}$ から求めた補正係数によって補正しきれず，誤差が生じ たためと考えられる。 また, 凝固直後は集合組織や粗大 粒の影響により，オーステナイト相からの回折を得るこ とが難しく, 応力算出が困難であった. 


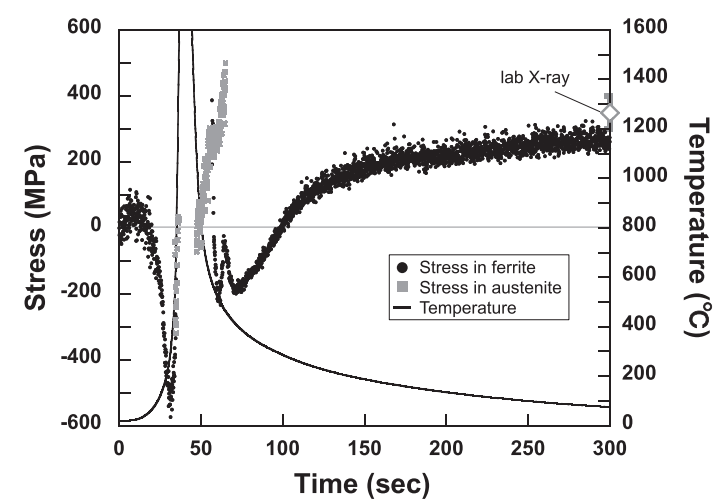

(a) General view

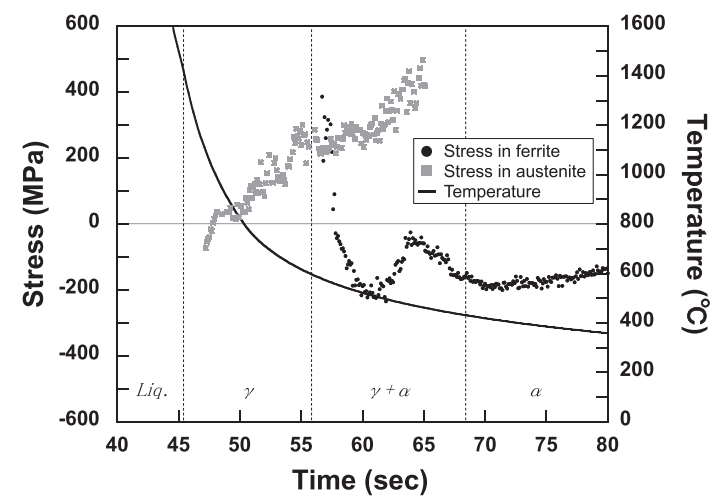

(b) Enlarged view

Fig. 9 Change of stresses during TIG welding in WM.

次に, 冷却時の相変態中の応力変化に注目する. Fig. 9 より, オーステナイト フフェライト変態が始まるととも に, オーステナイト相に引張応力が, フェライト相に圧縮 忘力が加わっていることが確認できる. これは, 各相の機 械的特性や相変態に起因した相応力であると考えられる. 熱膨張係数の差に起因した相応力について考えると, 高 温のオーステナイト/フェライト混合組織が冷却され収縮 しようとする際, 熱膨張係数の大きなオーステナイト相 はフェライト相よりも大きく収縮しようとする.この時, オーステナイト相とフェライト相は互いに連続であろう とするため, 互いに変形し, オーステナイト相に引張応力 が, フェライト相に圧縮応力がそれぞれ生じる. 一方, 相 変態に起因した相応力について考えると, オーステナイ 卜相がフェライト相に変態する際, フェライト相の体積 はオーステナイト相よりも大きくなる. この時, 先ほどと 同様にオーステナイト相とフェライト相は互いに連続で あろうとするため, 互いに変形し, オーステナイト相に引 張応力が, フェライト相に圧縮応力がそれぞれ生じる.つ まり，溶接金属部の相変態中に確認されたオーステナイ 卜相への引張応力と, フェライト相への圧縮応力は, 熱膨 張係数の差および相変態による体積変化に起因した相応 力と判断でき, これは, 相変態中の応力挙動を観察した報 告 ${ }^{16), 17)}$ の内容と合致した.

最後に, 相変態中の各相の体積比の変化と相応力の変 化に注目する. Fig. 9 より, 相変態開始直後にフェライト
相に大きな引張灾力が生じていることが確認できる．こ れは, 体積比の小さいフェライト相に応力集中が生じて いると考えられる. その後, フェライト相の体積比が 0.5 を超えると, 一時的にフェライト相に引張応力が生じ始 め, フェライト相, オーステナイト相の両方に引張応力が 生じている. そして, 相変態完了が近づくと, 相変態開始 時のフェライト相の場合と同様に, オーステナイト相に 応力集中が生じ, 高い引張応力が生じていることが確認 できる.

以上のように，放射光を用いた in-situ 計測技術を用い ることで, 溶接中の相変化と応力変化を同時に評価する ことができ, 相変態中の各相の応力変化や, 体積比の変化 に伴う応力変化の傾向を実験的に評価することができた.

\section{4 結 言}

本研究では，放射光を用いた in-situ 計測技術を用い， SM490A の溶接金属部における溶接時の過渡的な応力挙 動や冷却時の相変態に起因した応力変化を実験的に評価 した. 以下に本研究で得られた知見を示す.

（1）放射光を用いた in-situ 計測技術を用いることで，溶 接中の相変化と応力変化を同時に評価することがで きた。

（2）溶接金属部の泠却過程におけるオーステナイト $\rightarrow$ フ エライト変態中の各相に加わる応力の変化挙動をそ れぞれ独立して評価することができた。 そして，才 一ステナイト $\rightarrow$ ェライト変態中にはオーステナイ 卜相に引張応力が, フェライト相に圧縮応力が加わ ることが確認された。

(3) オーステナイト $\rightarrow$ オライト変態中の相応力を考え た場合, 熱膨張係数の差と相変態による体積膨張に よりオーステナイト相には引張灾力が加わり, フェ ライト相には圧縮応力が加わるが, in-situ 計測結果 はこれらの傾向と合致した。

（4）相変態開始直後と終了直前には体積比の小さいフェ ライト相とオーステナイト相にそれぞれ応力集中が 生じ, 高い引張応力が生じていることが確認できた.

（5）フェライト相の体積比が 0.5 を超えると, 一時的に フェライト相に引張応力が生じ, フェライト相, オ ーステナイト相の両方に引張応力が生じていた.

本研究は, 国立研究開発法人日本原子力研究開発機構 専用ビームライン BL22XU における公益財団法人高輝 度光科学研究センター専用ビームライン課題 (No. 2012B3722, 2013A3721, 2013A3722, 2013A3723, 2013B3722)の支援を得て行いました。 また，本研究の一 部はJSPS 科研費 24760606 の助成を受けたものです.こ こに記して心より感謝の意を表します.

\section{参 考 文 献}

1) A. Todoroki and H. Kobayashi, "Prediction of fatigue crack growth rate in residual stress field (application of superposition technique)", Transaction of the Japan Society of Mechanical Engineers A, Vol. 54, No. 497, pp. 30-37 (1986). 
2) L. F. Coffin, "A study of the effects of cyclic thermal stresses on a ductile metal", Transactions of ASME, Vol. 76, pp. 931-950 (1954).

3) D. Radaj, "Review of fatigue strength assessment of nonwelded and welded structures based on local parameters", International Journal of Fatigue, Vol. 18, No. 3, pp. 153-170 (1996).

4) N. Totsuka, M. Kamaya, K, Fujii and T. Terachi, "Initiation and prediction of stress corrosion cracking for alloy 600 in primary water of PWR", Institute of Nuclear Safety System, (2008).

5) M. Mochizuki, S. Matsushima, Y. Kubo and M. Toyoda, "Study on residual stress reduction by using phase transformation phenomena in welding material", Quarterly Journal of the Japan Welding Society, Vol. 23, No. 1, pp. 112-121 (2005).

6) H. Murata, N. Katoh and H. Tamura, "Effect of transformation on residual stress in welding-stress releasement by transformation superplasticity (part 5)", Quarterly Journal of the Japan Welding Society, Vol.11, No.4, pp.545-550 (1993).

7) J. W. Elmer, J. Wong, and T. Ressler, "In situ observations of phase transformations during solidification and cooling of austenitic stainless steel welds using time-resolved X-ray diffraction”, Scripta Materialia, Vol.43, No. 8, pp. 751-757 (2000).

8) Y. Komizo, T. Osuki, M. Yonemura and H. Terasaki, “Analysis of primary weld solidification in stainless steel using X-ray diffraction with synchrotron radiation", Transactions of the Welding Research Institute, Vol. 33, No. 2, pp. 143-146 (2004).

9) S. Zhang, T. Shobu, A. Shiro, T. Hashimoto, A. Tsuji, S. Okano and M. Mochizuki, "In-situ stress measurement in the heat affected zone during TIG welding process", 7th International Conference on Mechanical Stress Evaluation by Neutrons and Synchrotron Radiation (2013).
10) JSMS committee on X-ray study on mechanical behavior of materials, "Standard method for X-ray stress measurement - steel", JSMSSD-5-02, pp. 5-16 (2002).

11) Division of $X$-Ray Stress and Strain Measurements Committee for X-Ray Study on Deformation and Fracture of Solid, "Dependence of lattice strain on diffraction plane measured by Xray method: report of cooperative work of division", Journal of the Society of Materials Science, Japan, Vol. 20, No. 219, pp. 1257-1271 (1971).

12) A. L. Christenson and E.S. Rowland, "Residual stress in hardened high carbon steel”, Transaction of ASM, 45, pp. 638-676 (1953).

13) K. Tanaka, T. Kurimura, E. Matsui and Y. Akiniwa, "X-ray measurement of residual stresses in sintered silicon nitride", Journal of the Society of Materials Science, Japan, Vol. 36, No. 407, pp. 817-822 (1987).

14) E. Laine, "A high-speed determination of the volume fraction of ferrite in austenitic stainless steel by EDXRD", Journal of Physics F Metal Physics, Vol. 8, No. 7, pp. 1343-1348 (1978).

15) S. Okano, M. Tanaka and M. Mochizuki, "Arc physics based heat source modelling for numerical simulation of weld residual stress and distortion", Science and Technology of Welding and Joining, Vol.16, No.3, pp. 209-214 (2011).

16) P.G. Xua, Y. Tomota, S.C. Volgen, T. Suzuki, M. Yonemura and T. Kamiyama, "Transformation strain and texture evolution during diffusional phase transformation of low alloy steels studied by neutron diffraction", Reviews Advanced Materials, Vol.435 pp.389-395 (2013).

17) Y. Tomota, P.G. Xu, T. Kamiyama and E.C. Oliver, "In situ TOF neutron diffraction during phase transformation in an engineering steel", Nuclear Instruments and Methods in Physics Research A, Vol.600, pp.313-315 (2009). 